\title{
PERAN VISUM ET REPERTUM DALAM PENEGAKAN HUKUM PIDANA PADA KASUS KEMATIAN TIDAK WAJAR DI KOTA MANADO
}

\author{
Yuke N. Langie \\ Djemi Tomuka \\ Erwin G. Kristanto
}

\author{
Bagian Ilmu Kedokteran Forensik dan Medikolegal Fakultas Kedokteran \\ Universitas Sam Ratulangi - RSUP Prof. Dr. R. D. Kandou Manado \\ Email: keykeylangie@gmail.com
}

\begin{abstract}
Crimes related to life and body of human being such as homicides, suicides, and traffic accidents are commonly encountered in daily life. Death often occurs suddenly and sometimes in unexpected and unnatural ways. In order to obtain the chronology of a death case acurately, law enforcers perform several methods; one of them is the assistance of a forensic expert. Visum et repertum is a written report made by a doctor at the request of an authority for the benefit of the court upon what can be seen and found from the crime evidences. In this study, we used data of unnatural death cases in 2013-2014 obtained from the police, the court, and the Department of Forensic and Medicolegal of Prof Dr R. D. Kandou Hospital, Manado. The results showed that several kinds of criminal offences, in this case unnatural deaths, tended to increase from 2013 (39 cases) to 2014 (107 cases). Of the 39 cases in 2013 there were only 7 autopsies (17,9\%) and of the 107 death cases in 2014 there was only 1 autopsy (0.9\%). However, data of unnatural death cases of the court of Manado showed a decrease of death case numbers from 2013 (108 cases) to 2014 (58 cases). Conclusion: There was an increase of the unnatural death case number from 2013 to 2014 in Manado, however, the roles of visum et repertum and autopsy in these cases were still low.
\end{abstract}

Keywords: criminal offense, visum et repertum

\begin{abstract}
Abstrak: Tindak pidana adalah suatu kejahatan yang telah diatur dalam Kitab Undangundang Hukum Pidana (KUHP). Peristiwa pelanggaran hukum yang menyangkut tubuh dan nyawa manusia seperti kasus pembunuhan, bunuh diri, dan kecelakaan lalu lintas (KLL) sering ditemukan dalam kehidupan sehari-hari. Kematian sering terjadi tanpa diduga, tibatiba, dan dengan cara yang terkadang tampak tidak wajar. Penengak hukum melakukan berbagai cara untuk dapat mengetahui dengan jelas kronologi kasus pembunuhan tersebut; salah satu cara ialah dengan bantuan ahli forensik. Visum et repertum adalah laporan tertulis yang dibuat oleh seorang dokter mengenai segala sesuatu yang dilihat dan ditemukan pada pemeriksaan barang bukti atas permintaan yang berwenang untuk kepentingan peradilan. Hasil penelitian memperlihatkan bahwa data Polresta Kota Manado terdapat peningkatan berbagai macam tindak pidana yang terjadi serta sebab pembunuhan dari tahun 2013 ke tahun 2014. Dari 39 kasus kematian pada tahun 2013 Polresta Manado hanya meminta 7 kasus $(17,9 \%)$ untuk diautopsi, dan dari 107 kasus kematian pada tahun 2014 hanya 1 kasus untuk di autopsi $(0,9 \%)$. Data dari kasus pembunuhan yang diterima di Kejaksaan Negeri Manado tahun 2013 dan tahun 2014 memperlihatkan terjadinya penurunan dari tahun 2013 (108 kasus) ke tahun 2014 (58 kasus) yang berbeda dengan data Polresta Manado. Simpulan: Walaupun terdapat peningkatan kasus kematian tidak wajar di kota Manado dari tahun 2013 ke tahun 2014 peran visum et repertum dan autopsi pada kasus tersebut masih rendah.
\end{abstract}

Kata kunci: tindak pidana, visum et repertum 
Tindak Pidana atau dalam bahasa Belanda disebut strafbaar feit merupakan istilah yang diterjemahkan ke dalam bahasa Indonesia dengan berbagai arti diantaranya ialah: tindak pidana, delik, perbuatan pidana, peristiwa pidana, maupun perbuatan yang dapat dipidana. Kata Strafbaar feit terdiri dari 3 kata, yakni straf, baar, dan feit. Berbagai istilah yang digunakan sebagai terjemahan dari strafbaar feit itu, ternyata straf diterjemahkan sebagai pidana dan hukum. Perkataan baar diterjemahkan dengan dapat dan boleh, sedangkan untuk kata feit diterjemahkan dengan tindak, peristiwa, pelanggaran dan perbuatan. ${ }^{1}$

Tindak Pidana adalah suatu kejahatan yang telah diatur dalam Kitab Undangundang Hukum Pidana (KUHP). Peristiwa pelanggaran hukum yang menyangkut tubuh dan nyawa manusia seperti kasus pembunuhan, banyak ditemukan dalam kehidupan sehari-hari. Kematian sering terjadi tanpa diduga, tiba-tiba, dan dengan cara yang terkadang tampak tidak wajar.

Ilmu forensik adalah cabang ilmu pengetahuan yang ditujukan untuk membantu proses peradilan, terutama dalam bidang pembuktian. Dalam ilmu forensik itu sendiri terdapat berbagai cabang ilmu yang berasal dari ilmu pengetahuan lain antara lain yaitu kedokteran, hukum, kimia, psikologi, dan antropologi yang menjadikan obyek kajian yang sangat luas seperti kedokteran forensik, kimia forensik, psikologi forensik, antropometri forensik dan hukum kedokteran kehakiman yang didalamnya mencakup ilmu forensik dan hukum. ${ }^{2}$

Ilmu kedokteran forensik, juga dikenal sebagai legal medicine, adalah salah satu cabang spesialistik dari ilmu kedokteran yang mempelajari pemanfaatan ilmu kedokteran untuk kepentingan penegak hukum serta keadilan. Sebagai ilmu pengetahuan dengan fungsi pembuktian 'benda bukti' lewat 'saksi diam' pada pokoknya maupun akhirnya akan tetap bersandar pada perangkat hukum (positif) yang berlaku di Indonesia. ${ }^{3}$
Di dalam KUHAP terdapat pasal yang berkaitan dengan kewajiban dokter, untuk membantu peradilan yaitu dalam bentuk keterangan ahli, pendapat orang ahli, ahli kedokteran kehakiman, dokter, dan surat keterangan dari seorang ahli yang memuat pendapat berdasarkan keahliannya mengenai sesuatu hal atau sesuatu keadaan yang diminta secara resmi dari padanya (KUHAP: Pasal 187 butir c). ${ }^{4}$

Visum et repertum (VeR) merupakan suatu laporan tertulis dari dokter (ahli) yang dibuat berdasarkan sumpah mengenai apa yang dilihat dan diketemukan atas bukti hidup, mayat, fisik atau barang bukti lain, kemudian dilakukan pemeriksaan menurut pengetahuan sebaik-baiknya. ${ }^{5}$ Visum et repertum sering diminta oleh pihak penyidik (polisi) kepada dokter menyangkut perlukaan pada tubuh manusia. ${ }^{6}$

Penelitian ini bertujuan untuk mengetahui sejauh mana peran visum et repertum dalam usaha memecahkan kasuskasus kematian tidak wajar yaitu kasus pembunuhan, bunuh diri dan kecelakaan lallu lintas di kota Manado

\section{VISUM ET REPERTUM}

Visum et repertum yang dalam ilmu kedokteran forensik biasanya dikenal sebagai "visum" berasal dari kata 'visual' yang berarti melihat dan 'repertum' yaitu melaporkan sehingga jika digabungkan menjadi "apa yang dilihat dan diketemukan". 5

Pendapat dokter forensik yang dituangkan dalam sebuah visum et repertum sangat diperlukan oleh hakim sebagai sebuah keputusan di persidangan. Seorang hakim sebagai pemutus perkara tidak dibekali dengan ilmu-ilmu yang berhubungan dengan kedokteran forensik. Hasil pemeriksaan serta laporan tertulis ini akan digunakan untuk petunjuk sebagaimana yang dimaksud pada pasal 184 KUHAP tentang alat bukti yang sah. Hal ini mengartikan bahwa visum et repertum bukan saja sebagai petunjuk pada suatu perkara tindak pidana namun juga 
mendukung proses persidangan di pengadilan.

Dalam pasal 10 Surat Keputusan Menteri Kehakiman No. M04/UM/01.06 tahun 1983 dinyatakan bahwa "Hasil pemeriksaan ilmu kedokteran kehakiman disebut visum et repertum”. Keterangan tertulis yang dibuat oleh dokter atas permintaan tertulis (resmi) penyidik tentang pemeriksaan medis terhadap seseorang manusia baik hidup maupun mati ataupun bagian dari tubuh manusia, berupa temuan dan interpretasinya, di bawah sumpah dan untuk kepentingan peradilan. ${ }^{5}$ Dengan demikian, menurut KUHAP keterangan yang diberikan oleh ahli kedokteran kehakiman atau dokter atau ahli lainnya disebut visum et repertum. ${ }^{5,7}$

Visum et repertum terdiri dari beberapa jenis, yaitu: ${ }^{8}$

\section{Visum untuk korban hidup}

a. Visum seketika (definitive): Visum yang langsung diberikan setelah korban selesai diperiksa dan merupakan jenis visum ini yang paling banyak dibuat oleh dokter.

b. Visum sementara: Visum yang diberikan pada korban yang masih dalam perawatan. Biasanya visum jenis ini diperlukan penyidik untuk menentukan jenis kekerasan sehingga dapat menahan tersangka atau sebagai petunjuk dalam menginterogasi tersangka. Dalam visum sementara ini, belum dituliskan kesimpulan.

c. Visum lanjutan: Visum ini dilakukan bila luka korban telah dinyatakan sembuh. Alasan lain pembuatan visum jenis ini ialah bila korban pindah rumah sakit, korban pindah dokter, atau korban pulang paksa.

\section{Visum untuk mayat (jenazah)}

Bila korban telah meninggal dunia maka dokter forensik membuat visum. Dokter forensik menulis kualifikasi luka pada bagian kesimpulan. Visum yang dibuat berdasarkan otopsi lengkap atau dengan kata lain berdasarkan pemeriksaan luar dan pemeriksaan dalam pada mayat.

a. Visum et repertum tempat kejadian perkara (TKP): dibuat setelah dokter selesai melaksananakan pemeriksaan di TKP.

b. Visum et repertum penggalian jenazah: dibuat setelah dokter selesai penggalian jenazah.

c. Visum et repertum psikiatri: dibuat pada terdakwa yang saat pemeriksaan di sidang pengadilan ditemukan gejalagejala penyakit jiwa.

d. Visum et repertum barang bukti: visum terhadap barang bukti yang ditemukan sehubungan dengan tindak pidana, sebagai contoh: darah, pisau, peluru, rambut, dan tulang.

\section{PENEGAKAN HUKUM PIDANA}

Indonesia adalah Negara Hukum. Amanat konstitusi sebagaimana yang tertera pada pasal 1 ayat (3) UUD 1945. Negara hukum dalam arti yang luas, yang menjamin hak-hak dan kewajiban asasi Negara serta manusia, memajukan kesejahteraan rakyat dan keadilan sosial berdasarkan Pancasila. Idealnya di negara hokum, kekuasaan yang menjalankan pemerintahan harus berdasarkan pada hukum, tunduk pada kedaulatan hukum, dan bertujuan untuk menjalankan ketertiban hukum demi terwujudnya suatu kehidupan yang damai, aman, dan tentram, namun fakta membuktikan bahwa Indonesia belum dapat berjalan sebagaimana mestinya akibat lemahnya penegakan hukum di Indonesia. ${ }^{9}$

\section{Kematian tidak wajar}

Membunuh berasal dari kata bunuh yang berarti menghilangkan nyawa, mematikan”. Menurut Imam Malik pembunuhan terdiri atas dua, yaitu: pembunuhan sengaja dan pembunuhan kesalahan. Pembunuhan sengaja adalah suatu perbuatan dengan maksud menganiaya dan mengakibatkan hilangnya nyawa atau jiwa orang yang dianiaya, baik penganiayaan itu dimaksudkan untuk membunuh ataupun tidak dimaksudkan 
membunuh sedangkan pembunuhan kesalahan adalah suatu perbuatan yang mengakibatkan kematian yang tidak disertai niat penganiayaan. ${ }^{10}$

\section{METODE PENELITIAN}

Penelitian ini merupakan penelitian deskriptif retrospektif dengan memanfaatkan data sekunder dari Polresta Kota Manado, Kejaksaan Kota Manado, serta Bagian Forensik dan Medikolegal RSUP Prof. Dr. R.D Kandou Manado yang dilakukan pada bulan November sampai dengan Desember 2014. Variabel yang diteliti ialah jumlah kasus kematian tidak wajar yakni kasus pembunuhan, kasus bunuh diri, dan kasus kecelakaan lalu lintas (KLL).

\section{HASIL PENELITIAN DAN BAHASAN}

Pada grafik kasus pembunuhan yang diambil di Polresta Manado terlihat adanya peningkatan jumlah kasus pembunuhan dari tahun 2013 ke tahun 2014, kecuali pada bulan November dan Desember (Gambar 1).

Pada kajian peristiwa yang menyebabkan kasus pembunuhan meningkat d Polresta Kota Manado dapat dilihat berbagai macam tindak pidana yang terjadi serta sebab pembunuhan yang meningkat dari tahun 2013 ke tahun 2014 (Tabel 1). Pada kasus penganiayaan terjadi peningkatan hampir 3 kali lipat; kasus pencabulan meningkat 3 kali lipat; kasus kekerasan dalam rumah tangga (KDRT) meningkat 2 kali lipat; dan kasus pemerkosaan meningkat 1 kali lipat. Penemuan mayat pada tahun 2013 tidak ada sedangkan pada tahun 2014 ditemukan 5 kasus. Mayat dengan tidak adanya keterangan (TK) pada tahun 2013 ditemukan 3 kasus sedangkan tahun 2014 tidak ada. Data Polresta Manado menunjukkan jumlah kematian tidak wajar meningkat hampir 3 kali lipat dari tahun 2013 ke tahun 2014 (Tabel 1).

Pada penelitian ini ditemukan bahwa penyidik kepolisian lebih banyak menggunakan visum pemeriksaan luar daripada hasil autopsi. Tabel 2 memperlihatkan dari 39 kasus kematian pada tahun 2013 Polresta Manado hanya meminta 7 kasus (17,9\%) untuk diautopsi dan dari 107 kasus pada tahun 2014 hanya 1 kasus untuk di autopsi (0,9\%) (Tabel 2).

Data dari kasus pembunuhan yang diterima di Kejaksaan Negeri Manado tahun 2013 dan tahun 2014 memperlihatkan terjadinya penurunan dari tahun 2013 ke tahun 2014 (Tabel 3 dan Tabel 4) yang berbeda dengan hasil yang telah dipaparkan pada Tabel 1 dan 2 serta Gambar 1.

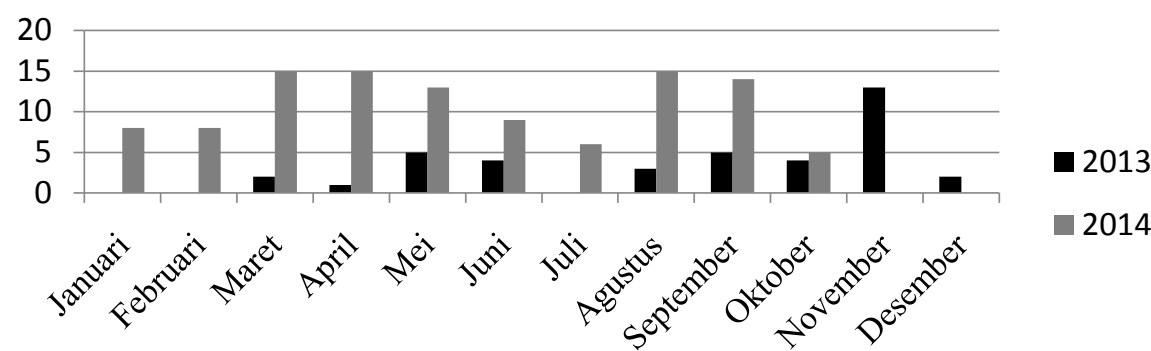

Gambar 1. Grafik kasus pembunuhan tahun 2013 dan 2014 diambil dari Polresta Manado

Tabel 1. Tindak pidana yang terjadi serta sebab pembunuhan pada tahun 2013 dan 2014

\begin{tabular}{cccccccc}
\hline Tahun & Penganiayaan & Pencabulan & KDRT & Pemerkosaan & Mayat & TK & Jumlah \\
\hline 2013 & 23 & 9 & 3 & 1 & 0 & 3 & 39 \\
2014 & 66 & 27 & 7 & 2 & 5 & 0 & 107 \\
\hline
\end{tabular}


Tabel 2. Kasus yang di autopsi di bagian BLU RSUP. Prof. R.D. Kandou atas permintaan Polresta kota Manado.

\begin{tabular}{lcc}
\hline \multirow{2}{*}{ Tempat pengambilan data } & \multicolumn{2}{c}{$\begin{array}{c}\text { Jumlah } \\
\text { kasus }\end{array}$} \\
\cline { 2 - 3 } & $\mathbf{2 0 1 3}$ & $\mathbf{2 0 1 4}$ \\
\hline Polresta Kota Manado & 39 & 107 \\
Autopsi di RSUP Prof. Dr. & 7 & 1 \\
R. D. Kandou & 17,9 & 0,9 \\
\hline
\end{tabular}

Tabel 3. Kasus-kasus pembunuhan yang sampai di Kejaksaan Negeri Manado atau yang di sebut SPDP (Surat Pemberitahuan Dimulainya Penyidikan)

\begin{tabular}{ccccc}
\hline \multicolumn{4}{c}{ Kasus pembunuhan yang sampai di } \\
Kejaksaan Negeri Manado \\
\hline \multirow{2}{*}{2013} & \multicolumn{2}{c}{2014} \\
Bulan & pasal & pasal & pasal & pasal \\
& 351 & 338 & 351 & 338 \\
Januari & 6 & 2 & 5 & 1 \\
Februari & 11 & 3 & 4 & 2 \\
Maret & 6 & 0 & 4 & 3 \\
April & 10 & 5 & 2 & 0 \\
Mei & 3 & 0 & 10 & 2 \\
Juni & 2 & 3 & 5 & 1 \\
Juli & 3 & 1 & 0 & 0 \\
Agustus & 3 & 1 & 3 & 2 \\
September & 9 & 3 & 9 & 0 \\
Oktober & 6 & 12 & 5 & 0 \\
November & 10 & 2 & 0 & 0 \\
Desember & 8 & 3 & 0 & 0 \\
Jumlah & 77 & 35 & 47 & 11 \\
\hline
\end{tabular}

Pasal 351: Penganiayaan

Pasal 338: Kejahatan terhadap nyawa

(pembunuhan)

Tabel 4. Kasus pembunuhan di Kejaksaan Negeri Manado pada tahun 2013 dan 2014

\begin{tabular}{ccc}
\hline Tahun & Kasus Pembunuhan & $\mathbf{\%}$ \\
\hline 2013 & 108 & 63 \\
2014 & 58 & 37 \\
\hline
\end{tabular}

Pada kasus kematian tidak wajar yaitu kasus bunuh diri dari berbagai sumber tempat penelitian yang diambil hanya ditemukan 1 kasus bunuh diri yaitu kasus gantung diri dimana data diperoleh dari Bagian Forensik dan Medikolegal RSUP Prof. Dr. R.D Kandou Manado.

Kasus gantung diri tersebut terjadi pada bulan Mei tahun 2014 di Kota Manado dan tidak ditemukan kasus bunuh diri pada tahun 2013. Jumlah kasus kematian tidak wajar akibat KLL memperlihatkan penurunan pada tahun 2014 (Tabel 5).

Tabel 5. Kasus kematian tidak wajar pada kecelakaan lalu lintas yang menyebabkan korban meninggal dunia

\begin{tabular}{ccc}
\hline Tahun & $\begin{array}{c}\text { Kasus KLL di RSUP. } \\
\text { Prof. Dr. R. D. Kandou }\end{array}$ & \% \\
\hline 2013 & 40 & 61,5 \\
2014 & 25 & 38,5 \\
\hline
\end{tabular}

\section{SIMPULAN}

Dari hasil penelitian dapat disimpulkan bahwa walaupun terdapat peningkatan kasus pembunuhan di kota Manado dari tahun 2013 ke tahun 2014 peran visum et repertum pada kasus kematian tidak wajar masih rendah.

\section{SARAN}

Disarankan pada aparat hukum baik polisi maupun jaksa untuk mensosialisasikan kepada masyarakat mengenai pentingnya peran visum et repertum pada penyidikan.

\section{DAFTAR PUSTAKA}

1. Kansil CST. Pengantar ilmu hukum dan tata hukum Indonesia. Jakarta: Balai Pustaka, 2010.

2. Musa B. Peranan ilmu forensik - scribd [internet] 2011 [cited 2014 Dec 6] Available from: http://www.scribd. com/doc/57650686/peranan-ilmuforensik\#scribd

3. Chazawi A. Pengantar Hukum Pidana Bag 1. Jakarta: Grafindo, 2002. 
4. Idries A. Pedoman Ilmu Kedokteran Forensik. Jakarta: 1989; p. 3.

5. Hidayat F. Visum et Repertum. [internet] 2011 [cited 2014 Dec 6]. Available from: https://ferli1982.wordpress.com/ 2011/03/06/visum-et-repertum/

6. Herkuntanto. Peningkatan kualitas pembuatan visum et repertum (VeR) kecederaan di rumah sakit melalui pelatihan dokter unit gawat darurat (UGD). JPMK 2005;8(3):163-9.

7. Mershinta, Arimawan K. Peranan visum et repertum sebagai upaya mengungkap tindak pidana pembunuhan. Studi kasus putusan PN Surabaya No: 3054/ Pid.B/2010/PN.SBY (Undergraduate thesis). Faculty of Law. [internet] 2011 [cited 2014 Nov 5]. Available from: http://eprints.upnjatim.ac.id/1845/

8. Kekuatan pembuktian visum et repertum [internet]. 2012 [cited 2014 Dec 7] Available from: ejurnal.ung.ac.id/index. php/JL/article/download/880/821.

9. Tobing J. Leimene Institute. Republik Indonesia adalah Negara Kesatuan [internet] 2011. [cited 2014 Dec 6]. Available from: http://www.leimena. org/en/page/v/373/republik-indonesiaadalah-negara-kesatuan-negarademokrasi-konstitusional-dan-negarahukum.

10. Chapter II. Pdf- USU institutional Repository [internet] VP sari. 2014. [cited 2014 Nov 5]. Available from: http://repository.usu.ac.id/bitstream/123 456789/39613/3/Chapter\%20II.pdf. 